\title{
Data integration methodology that couples novel bioreactor monitoring tools, automated sampling, and applied mathematics to redefine bioproduction processes
}

Lisa J Graham*, Jeffrey F Breit, Lynn A Davis, Corey C Dow-Hygeland, Brandon J Downey

From 23rd European Society for Animal Cell Technology (ESACT) Meeting: Better Cells for Better Health Lille, France. 23-26 June 2013

Cell physiology dynamically affects the nutrient requirements of a culture. It is critical to obtain data over appropriate time intervals to assess the impact of process conditions on the cell population. By optimizing bioreactor operation, feed strategies and media composition, we can limit the number of experiments to obtain the empirical data sets.

For this poster, we present an emerging processdevelopment methodology that is based on applying novel and existing bioreactor monitoring technologies, coupled with applied mathematics, to bioreactor processes. This approach employs tools like dielectric spectroscopy, aseptic autosamplers, and cell-based bioreactor models. We will illustrate how information gained from these tools can be coupled through utilization of the proper data integration and applied mathematics techniques.

The knowledge gained using this improved process development methodology also supports a less-invasive monitoring and feedback system, and can be implemented using a customized bioreactor control code.

Published: 4 December 2013

doi:10.1186/1753-6561-7-S6-P115

Cite this article as: Graham et al: Data integration methodology that couples novel bioreactor monitoring tools, automated sampling, and applied mathematics to redefine bioproduction processes. BMC Proceedings 2013 7(Suppl 6):P115.

* Correspondence: lisa.graham@bendresearch.com Bend Research Inc, Bend, OR, USA

Biomed Central
Submit your next manuscript to BioMed Central and take full advantage of:

- Convenient online submission

- Thorough peer review

- No space constraints or color figure charges

- Immediate publication on acceptance

- Inclusion in PubMed, CAS, Scopus and Google Scholar

- Research which is freely available for redistribution 